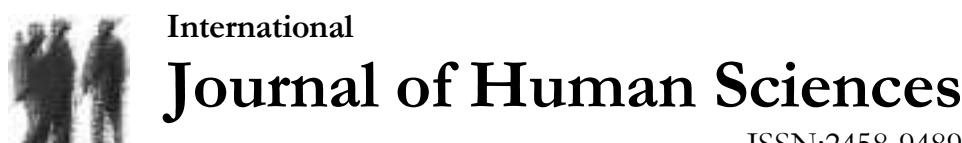 \\ ISSN:2458-9489
}

Volume 15 Issue 1 Year: 2018

\section{Hospitalized children's opinions about peripheral venous access process (PVAP) ${ }^{1}$}

\author{
Nazan Çakırer Çalbayram² \\ Sebahat Altunda $\breve{g}^{3}$
}

\begin{abstract}
Research problem/aim: This study was carried out to determine the thoughts of school-age (612 years old) children about peripheral venous access process. Method: The study was carried out in qualitative descriptive design using semi-structured interview method. The universe of the study was composed of children aged between 6 and 12 hospitalized in the aforementioned hospital. Findings: The children who were informed before the process said the warnings were, "take a deep breath, don't move your hand, calm down". The children reported that they felt "excitement, sadness, pain, and fear" while the vascular access intervention was being performed. It was observed that the children had many negative emotions and experiences about vascular access process. Conclusions: Children may need both physical and psychological support for invasive process, such as vascular access process. Nurses as primary caregivers should give this support to children.
\end{abstract}

Keywords: hospitalized children, peripheral venous access process, painful process, stress, nurse

\section{Introduction}

Hospitalization is a procces that can be disturbing to varying extents depending on the age of the child and the reason for hospitalization. In addition, the hospital environment is a strange place that is full of unknown things for the child. Children confront needles, painful-hurting process, unfamiliar people like physicians and nurses, and an environment that they are totally unfamiliar with ${ }^{1}$. The most common painful process are drawing blood, the peripheral venous access process (PVAP), and intramuscular applications, and these process are usually performed by nurses. Pediatric patients are not considered in painful process. The reason for this is the instant necessity for carrying out the process. In this case, the nurses focus on the process regardless of the child's cooperation, and as a result, the stress level of the child increases ${ }^{2}$. It has been found in Carmen et al. that very painful medical process are the more stressful ones for children than the sickness itself ${ }^{3}$. In many studies, children's responses to painful and bothering medical process have been determined as anxiety, agitation, crying, rigidity and resistance in muscles, emotional withdrawal, escape behaviors and aggression ${ }^{4-8}$.

\footnotetext{
${ }^{1}$ This paper was presented at the I. International Health Sciences Congresss 2017, Adnan Menderes University Aydın, 29 June-1 July 2017, Turkey.

2PhD., Ankara University, Ankara University, Health Science Faculty, Midwifery, calbayram@ankara.edu.tr

${ }^{3}$ Assistant Professor, PhD. Pamukkale University, Health Science Faculty, Nursing, saltundag@pau.edu.tr
} 
Additionally, the reactions of children to painful and stressful process and their refusal of these process can affect the performance and emotional state of the health personnel who perform these process. When children's requests are not taken into consideration during medical process, there may be some disagreements between the health worker and the parents following the process $^{2,9}$.

Children have the right to get information about the process to be performed, but this right is often forgotten or neglected. The fact that children are not informed about the treatments and process to be implemented increases their fear and anxiety. Nurses must be aware of the cognitive developmental characteristics, fears, and expectations of the child in every age group in order to prepare the child for the process ${ }^{10}$.

\section{Purpose}

The current study aims to determine the views of school children (6-12 years) on PVAP

\section{Method and material}

\subsection{Population and sample selection}

The universe of the study consisted of hospitalized children aged between 6 and 12. No sampling process was applied in the study; therefore, all the children (30), who agreed to participate in the study, were included in the study. The school starting age was considered as the lower limit for the children since children of this age were thought to be able to express their opinions on PVAP verbally; thus, 6-12-year-old children were involved in the study. The children included in the study were conscious and able to communicate. The interviews were conducted by the researchers between 01 March 2017 and 01 April 2017.

Inclusion criteria. The following were the inclusion criteria:

- hospitalized pediatric patients

- 6-12 years old

- having no mental retardation

- having no communication problems

- requiring no isolation due to the disease

- having no psychiatric problem

- accepting to participate in the study (volunteer)

\subsection{Type of study}

The study was designed in qualitative, cross-sectional, and descriptive type and it was carried out with semi-structured interview method.

\subsection{Data collection}

The data of the study were collected through a "Data Collection Form" consisting of 16 questions prepared by the researchers. The items in the form questioned the child's sociodemographic information and views on PVAP (Figure 1). The interviews were conducted with the hospitalized children by the researchers. After the researcher introduced himself/herself and informed the children about the study, the consent of the children was taken, and then the children were requested to respond to the questions in the semi-structured question form. The responses of the children were written verbatim in the data collection form. The "interview" technique was used as data collection tool. Each interview lasted 15-20 minutes. 
Figure 1. Child's views on PVAP

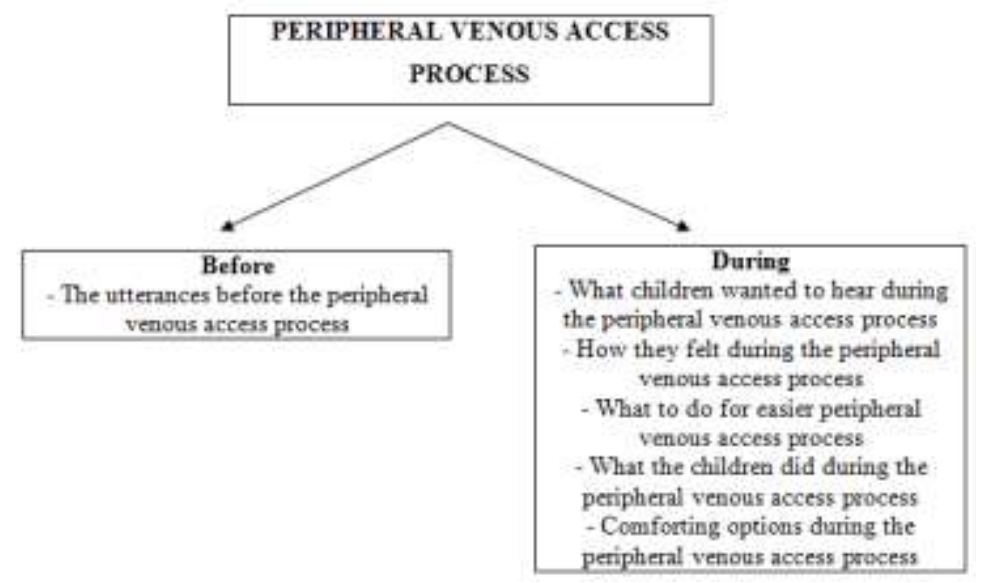

3.4. Limitations of the study

The study was limited to the findings obtained from the sampling.

\subsection{Research ethics}

The families and the children were informed. The participants were given written information about the study and confidentiality was guaranteed. Participation and withdrawal were optional. The Research Ethical Review Board of the University approved the study (13.02.2017/3/44). The study was conducted in full accordance with the Declaration of Helsinki (2013).

\subsection{Evaluation of data}

The qualitative data obtained by the interview technique were digitized to obtain frequencies and percentages.

\section{Results}

The mean age of the children participating in the study was 9.7 (min: 6, max: 12), $50 \%$ were female, $50 \%$ were male, and $76.7 \%$ had core family structure. $43.3 \%$ of the children had not previously been hospitalized, $90 \%$ had a PVAP applied by a nurse, $66.7 \%$ had a previous PVAP, and the peripheral venous access insertion in $63.3 \%$ was implemented in just one attempt. $43.3 \%$ of the children were informed before the process.

Table 1. The utterances before the peripheral venous access process (n: 13$) *$

\begin{tabular}{lcc}
\hline Utterances & $\mathbf{n}$ & $\mathbf{\%}$ \\
\hline Breathe deeply & 3 & 23.1 \\
$\begin{array}{l}\text { Do not pull your hand, the venipuncture will } \\
\text { disappear }\end{array}$ & 2 & 15.4 \\
Clench your hand & 2 & \\
Calm down & 2 & 15.4 \\
This is for your recovery & 1 & 15.4 \\
I have to insert this & 1 & 7.7 \\
It will hurt a bit & 1 & 7.7 \\
Where will I insert the catheter & 1 & 7.7 \\
Look at the other side & 1 & 7.7 \\
It won't hurt & 1 & 7.7 \\
Close your eyes & 1 & 7.7 \\
Which grade are you in & 1 & 7.7 \\
\hline
\end{tabular}

*The percentages were calculated over $\mathrm{n}$ as there were multiple responses. 
The children who stated that an explanation was made said the most frequent utterances were "breathe deeply", "don't pull your hand", and "calm down". The most stunning statement made during the PVAP was "We will go in here; when blood comes, we will not try again" (12 y, E).

Table 2. What children wanted to hear during the peripheral venous access process (n: 30$)^{*}$

\begin{tabular}{lcc}
\hline Utterances & $\mathbf{n}$ & $\mathbf{\%}$ \\
\hline I don't know. & 12 & 40.0 \\
How will it be inserted? I wish they explained the & 7 & 23.3 \\
process. & 4 & \\
Whether it will hurt or not & 3 & 13.3 \\
Nothing & 2 & 6.0 \\
They should tell us why it is inserted. & 2 & 6.6 \\
What would happen if they had not inserted the & 1 & 3.3 \\
catheter? & 1 & 3.3 \\
How long will it take? & 1 & 3.3 \\
How does it work? & & \\
How will it be taken out? & & \\
\hline
\end{tabular}

*The percentages were calculated over $\mathrm{n}$ as there were multiple responses.

The children who stated that no explanation was made stated that they could be informed about "how it will be inserted", "whether it will hurt", and "why it will be inserted".

The statements of the children:

"It would be better if I didn't have it, I wonder about the plastic in it, I wonder how it works, how do things like water go through it?" (12 y, K)

"It will be better if they explain comprehensively what they will do" (12 y, E)

"Nothing, I would get scared more " (12 y, K)

"Nothing would comfort me" (10 y, K)

Table 3. How they felt during the peripheral venous access process (n: 30)*

\begin{tabular}{lcc}
\hline Utterances & $\mathbf{n}$ & $\mathbf{\%}$ \\
\hline Pain & 20 & 66.7 \\
Nothing & 6 & 20.0 \\
Excitement & 3 & 10.0 \\
Fear & 2 & 6.6 \\
Ache & 2 & 6.6 \\
Sadness & 1 & 3.3 \\
A slight itching & 1 & 3.3 \\
I wanted it to end as soon as possible & 1 & 3.3 \\
\hline
\end{tabular}

*The percentages were calculated over $\mathrm{n}$ as there were multiple responses.

The children stated that they felt "pain, excitement, sadness, and fear" during the PVAP.

The statements of the children:

"It hurt so much; I wanted it to end as soon as possible (10 y, K)

"It burnt a lot; as if a fork pierced my hand $(6 \mathrm{y}, \mathrm{E})$ 
Çakırer Çalbayram, N., \& Altundağ, S. (2018). Hospitalized children's opinions about peripheral venous access process (PVAP). Journal of Human Sciences, 15(1), 243-250. doi:10.14687/ihs.v15i1.5174

Table 4. What to do for easier peripheral venous access process (n: 30 )*

\begin{tabular}{lcc}
\hline Utterances & $\mathbf{n}$ & $\mathbf{\%}$ \\
\hline I don't know & 13 & 43.3 \\
Anesthetizing the place to be accessed & 4 & 13.3 \\
Nothing & 3 & 10.0 \\
Performing it slowly & 2 & 6.6 \\
They can try inserting the needle through the & 1 & 3.3 \\
serum line. & 1 & 3.3 \\
They can try administering a sedative at the outset & 1 & 3.3 \\
Using gauze to soften the place where the catheter & & 3.3 \\
will be inserted can make it easier. & 1 & 3.3 \\
They can try blowing it & 1 & 3.3 \\
They can try not pressing on my arms while & & 3.3 \\
inserting it. & 1 & 3.3 \\
They can try not moving the needle inside the & & \\
vessel & 1 & \\
They can try anesthetizing. & 1 & wish there would be no needles.
\end{tabular}

*The percentages were calculated over $\mathrm{n}$ as there were multiple responses.

The children gave such responses as "I don't know", "anesthetizing the place to be accessed", "nothing can be done", and "performing it slowly" to the question about what to do for easier PVAP.

Some of the statements of the children:

"Instead of moving the needle desperately under the skin in an effort to open the vascular access, they can try another venous entry" (10 y, K).

"Vascular access can be achieved better if the equipment for children does not include a needle." (9 y, E).

"It is better not to have it at all. They can try not pressing on my arm while inserting it." ( 9 y, E)

Table 5. What the children did during the peripheral venous access process (n: 30$) *$

\begin{tabular}{lcc}
\hline Utterances & $\mathbf{n}$ & $\mathbf{\%}$ \\
\hline I cried. & 8 & 26.7 \\
I watched it. & 6 & 20.0 \\
I closed my eyes. & 6 & 20.0 \\
I screamed. & 6 & 20.0 \\
I look at my mom/dad/the nurse/around. & 6 & 20.0 \\
I clenched my hands. & 2 & 6.6 \\
I gritted my teeth. & 2 & 6.6 \\
I turned my head to the other side. & 1 & 3.3 \\
I pulled my arm. & 1 & 3.3 \\
I hugged mom. & 1 & 3.3 \\
\hline
\end{tabular}

*The percentages were calculated over $\mathrm{n}$ as there were multiple responses.

The children described what they did during the PVAP as "I cried, I watched it, I closed my eyes, and I screamed".

The response of one of the children: "I gritted my teeth, I screamed silently so as not to scare other children." (12 y, K) 
Çakırer Çalbayram, N., \& Altundağ, S. (2018). Hospitalized children's opinions about peripheral venous access process (PVAP). Journal of Human Sciences, 15(1), 243-250. doi:10.14687/jhs.v15i1.5174

Table 6. Comforting options during the peripheral venous access process (n: 30)*

\begin{tabular}{lcc}
\hline Utterances & $\mathbf{n}$ & $\mathbf{\%}$ \\
\hline My mom accompanying me & 23 & 76.7 \\
My dad accompanying me & 14 & 46.7 \\
My sister/brother accompanying me & 11 & 36.7 \\
Listening to music & 5 & 16.7 \\
Dreaming & 5 & 16.7 \\
Watching TV & 4 & 13.3 \\
My toy accompanying me & 4 & 13.3 \\
Seeing and examining the needle & 1 & 3.3 \\
The nurse talking to me & 1 & 3.3 \\
The person near me holding my hand & 1 & 3.3 \\
Inserting the catheter slowly & 1 & 3.3 \\
Being anesthetized & 1 & 3.3 \\
My grandfather & 1 & 3.3 \\
\hline
\end{tabular}

*The percentages were calculated over $\mathrm{n}$ as there were multiple responses.

Children stated that "the company of their mother/father/sister/brother" would comfort them most during the PVAP.

\section{Discussion}

Children may have to be hospitalized for diagnosis or treatment reasons at any time of their life. This is a critical experience that can leave negative traces on children. While an inpatient child is struggling with the disease, $\mathrm{s} /$ he also has to overcome painful procedures at the same time. One of the procedures that is commonly practiced and causes pain is peripheral venous catheter procedure. This procedure can be traumatic and fearful for the child. Fear and anxiety can be reduced by the psychological support and appropriate preparation of the child. The study was conducted to determine the views of school children (ages 6-12) on PVAP. Based on their cognitive developmental characteristics, children have the right to get information about the process to be performed, but this right is often overlooked ${ }^{10}$. Not providing the children with information about the painful process to be applied to them and the lack of people in company who they count on may increase children's reactions to the process and the pain arising from them ${ }^{10-12}$. GüdücüTüfekci (2007) determined that children who knew the reason for the painful process exhibited high pain tolerance ${ }^{13}$. In the study, only $43.3 \%$ of the children were found to be informed before the process. The children stated that they were instructed to "breathe deeply, not pull their hand, and calm down" before the process. However, it was determined that children wanted to know "how it would be inserted, whether it would hurt, and why it was inserted" before the process.

The children stated that they felt "pain, excitement, sadness, fear" during the PVAP, which is a painful intervention. When children refuse to have a painful medical process, a physical restraint is usually used if this process is to be performed clinically ${ }^{14}$. In the study, the statement of a child saying "it would be better not to have it; they had better not press on my arms during the process" shows the fact that physical restraints are exerted $(9 \mathrm{y}, \mathrm{E})$.

There are various methods recommended in the literature to facilitate the PVAP. These methods include balloon inflation ${ }^{15}$, ball squeezing ${ }^{15}$, local anesthetic application ${ }^{16,17}$, attracting to music $^{18}$, use of distraction cards ${ }^{19,20}$, and having the child watch a cartoon ${ }^{21-24}$. In the study, the children's response to the question about what can be done to facilitate the insertion was "anesthetizing the place to be accessed; and performing it slowly". In addition, the children stated that such options as "listening to music, dreaming, watching TV, having their toy with them " during the process would relieve their anxiety.

Painful process can be considered to be a source of stress. The presence of parents is extremely important so that children can effectively cope with stress ${ }^{25,26}$. In many studies, the most 
Çakırer Çalbayram, N., \& Altundağ, S. (2018). Hospitalized children's opinions about peripheral venous access process (PVAP). Journal of Human Sciences, 15(1), 243-250. doi:10.14687/ihs.v15i1.5174

important factor affecting the response of children to painful process has been determined to be the parents' presence with the child, the parents' reactions, and communication between the parent and the child $4,{ }^{27-29}$. In the current study, children stated that "the company of their mother / father/ brother / sister would comfort them most" during the PVAP. Parental involvement with the child during painful process may increase pain tolerance ${ }^{30,31}$. Studies have indicated that children want their parents to be present with them during painful process ${ }^{4}, 13,26,28,29,32$. Nurses should encourage the parents to be with the child during the process. Boztepe (2012) determined in a study that nurses supported family-centered care; however, they did not want parental involvement during painful process ${ }^{33}$.

\section{Conclusions and recommendations}

Children experience pain and fear during the PVAP. It has been seen that children have negative feelings and experiences related to the PVAP. Children may need both physical and psychological support in invasive process such as PVAP. Therefore, in the light of these findings:

- nurses should inform the child before the process;

- they should be open to communication with the child and answer the questions honestly;

- they should ask the child what s/he feels during the process;

- the nurse should collaborate with the child to facilitate the process;

- alternative ways should be used to facilitate the process (listening to music, dreaming, watching $\mathrm{TV}$, the presence of the favorite toy/doll, holding the hand); and

- parents should be allowed to accompany the child during the process.

\section{References}

1. Yavuzer, H. (2000). Eğitim ve Gelişim Özellikleriyle Okul Çağı Çocuğu. (1. baskı). İstanbul: Remzi Kitapevi.

2. Lloyd, M., Urquhart, G., Heard, A., Kroese, B. (2008). When a child says 'no': experiences of nurses working with children having invasive procedures. Paediatr Nurs. 20(4):29-34. DOI: 10.7748/paed2008.05.20.4.29.c8252

3. Carmen, B.Á. and Ana Fernández, M. (1997). Psychological Treatment of Evoked Pain and Anxiety by Invasive Medical Procedures in Paediatric Oncology. Psychology in Spain. 1(1), 17-36.

4. Gonzalez, JC., Routh, DK., Saab, PG., Armstrong, FD., Shifman, L., Guerra, E. (1989). Effects of parent presence on children's reactions to injections: behavioral, physiological, and subjective aspects. J Pediatr Psychol. 14(3):449-62.

5. Blount, RL., Landolf-Fritsche, B., Powers, SW., Sturges, JW. (1991) Differences between high and low coping children and between parent and staff behaviors during painful medical procedures. Journal of Pediatric Psychology. 16, 6, 795-809. https://www.ncbi.nlm.nih.gov/pubmed/1798015

6. Cardona, L. (1994). Behavioral approaches to pain and anxiety in the pediatric patient. Child andAdolescent Psychiatric Clinics of North America. 3, 3, 449-464.

7. Dahlquist, LM., Power, TG., Carlson, L. (1995) Physicianand parent behaviour during invasive pediatric cancer procedures:relationships to child behaviou rdistress. Journal of PediatricPsychology. 20, 4, 477-490.

8. Uman, LS., Birnie, KA., Noel, M., Parker, JA., Chambers, CT., McGrath, PJ. (2013). Psychological interventions for needlerelated procedural pain and distress in children and adolescents. Cocbrane Database Syst Rev.10:CD005179.

9. Carlson, KL., Broome, M., Vessey, JA. (2000). Using distraction to reduce reported pain, fear and behavioral distress in children and adolescents: a multisite study. J Soc of Pediatr Nurs. 5:75-85.

10. Çavuşoğlu, H. (2008). Hastaneye yatmanın çocuk ve aile üzerindeki etkileri. Çocuk Sağlı̆̆1 Hemşireliği Cilt 1. Genişletilmiş 9. Baskı. Ankara: Sistem Ofset Basımevi.

11. Yiğit, R (1997). Hastaneye yatmanın çocuk ve aile üzerine etkileri. Türk. Hemşireler Dergisi 17 (1): 21 28. 
Çakırer Çalbayram, N., \& Altundağ, S. (2018). Hospitalized children's opinions about peripheral venous access process (PVAP). Journal of Human Sciences, 15(1), 243-250. doi:10.14687/jhs.v15i1.5174

12. Pölkki T, Pietila AM, Rissanen L (1999). Pain in children: Qualitative research of Finnish schoolaged children's experiences of pain in hospital. International Journal of Nursing Practice. 5(1):21-28.

13. Güdücü-Tüfekci, F., Erci, B. (2007). Ağrılı İşlemler Sırasında Ebeveynlerin Bulunmasının Ve Bazı Faktörlerin Çocukların Ağrı Toleransına Etkisi. Journal of Anatolia Nursing And Health Sciences. 10; 2:30-40.

14. Nursing, R. C. O. (2007). Restraining, Holding Still and Containing Children and Young People Guidance for nursing staff. RCN, London.

15. Gupta, D., Agarwal, A., Dhiraaj, S., Tandon, M., Kumar, M., Singh, R.S., Singh, P.K., Singh, U. (2006). An Evaluation of Efficacy of Balloon Inflation on VenousCannulation Pain in Children: A Prospective, Randomized,Controlled Study. Anesth Analg. 102:1372-5.

16. Manner-T, M.D., Kanto J., Lisalo E., Lindberg R., Viinamäki O.,Scheinin M. (1987). Reduction of pain at venous cannulation in children with a eu tec tic mixture of lidocaine and prilocaine (EMLA® cream): comparison with placebo cream and no local premedication. Acta Anaesthesiol Scand. 31(8): 735-739.

17. Doyle, E., Freeman, J., Im, N.T., Morton, N.S. (1993). An evaluation of a new self-adhesive patch preparation of amethocaine for topical anaesthesia prior to venous cannulation in children. Anaesthesia. 48;12: 1050-1052.

18. Klassen, JA., Liang, Y., Tjosvold, L., Klassen, TP., Hartling, L. (2008). Music for pain and anxiety in children undergoing medical procedures: a systematic review of randomized controlled trials. Ambul Pediatr. 8:117-28.

19. Inal, S. and Kelleci, M. (2012). Distracting children during blood draw: Looking through distraction cards is effective in pain relief of children during blood draw. International Journal of Nursing Practice. 18: 210-219. http://dx.doi.org/10.1111/j.1440-172X.2012.02016.x

20. Canbulat, N., İnal, S., Sönmezer, H. (2014). Efficacy of distraction methods on procedural pain and anxiety by applying distraction cards and kaleidoscop in children. Asian Nurs Res (Korean Soc Nurs Sci). 8:23-28.

21. Weisenberg, M., Raz, T., Hener, T. (1998). The influence of film-induced mood on pain perception. Pain.76;365-75.

22. De Wied M, Verbaten MN. (2001). Affective pictures processing, attention and pain tolerance. Pain.90:163-72.

23. Landolt, MA., Marti, D., Widmer, J., Meuli, M. (2002). Does cartoon movie distraction decrease burned children's pain behavior? J Bum Care Rehabi. 23:61-5.

24. Dovney, LV, Zun, LS. (2012). The impact of watching cartoons for distraction during painful procedures in the emergency department. Pediatr Emerg Care. 28:1033-5.

25. Simons, J., Franck, L., Roberson, E. (2001). Parent involvement in children's pain care: views of parents and nurses. J Adv Nurs. 36(4):591-9

26. Broome ME. (2000). Helping parents support their child in pain. Pediatr Nurs. 26(3):315

27. Dahlquist, L. M., Pendley, J. S., Power, T. G., Landthrip, D. S., Jones, C. L., \& Steuber, C. P. (2001). Adult Command Structure and Children's Distress During the Anticipatory Phase of Invasive Cancer Procedures. Children's Health Care, 30(2), 151-167.

28. Turner, P. (1997). Establishing a protocol for parental presence in recovery. BrJ Nurs. 6(14):794-9.

29. Wolfram, RW., Turner, ED. (1996). Effects of parental presence during children's venipuncture. Acad Emerg Med. 3(1):58-64.

30. Cimete, G. (1994). A ğr1 kavramı. Türk Hemșireler Dergisi. 44(5-6):42-46.

31. Kocaman G (1994). .Ağrı, Hemşirelik Yaklaşımları.1.baskı. Saray Medikal Yayıncılık, İzmir.

32. Ross, DM., Ross, SA. (1984). Childhood pain: The school-aged child's viewpoint. Pain. 20: 179-191.

33. Boztepe H. (2012). "Pediatric nurse views regarding parental presence during a child's painful procedures/Pediatri hemsirelerinin agrili islemler sirasinda ebeveynlerin bulunmasi hakkında gorusleri." Agri: The Journal of the Turkish Society of Algology. 24(4):171-179. 